\title{
Parental Perceptions and Exposure to Advertising of Toddler Milk: A Pilot Study with Latino Parents
}

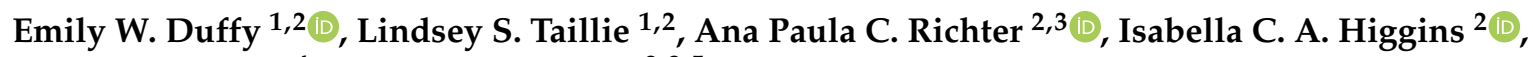 \\ Jennifer L. Harris ${ }^{4}$ and Marissa G. Hall $2,3,5$,* \\ 1 Department of Nutrition, Gillings School of Global Public Health, \\ University of North Carolina at Chapel Hill, Chapel Hill, NC 27599, USA; ebwelker@email.unc.edu (E.W.D.); \\ taillie@unc.edu (L.S.T.) \\ 2 Carolina Population Center, University of North Carolina at Chapel Hill, Chapel Hill, NC 27599, USA; \\ apcr@live.unc.edu (A.P.C.R.); ihiggins@email.unc.edu (I.C.A.H.) \\ 3 Department of Health Behavior, University of North Carolina at Chapel Hill Gillings School of Global \\ Public Health, Chapel Hill, NC 27599, USA \\ 4 Rudd Center for Food Policy \& Obesity, University of Connecticut, Hartford, CT 06103, USA; \\ jennifer.harris@uconn.edu \\ 5 School of Medicine, UNC Lineberger Comprehensive Cancer Center, \\ University of North Carolina at Chapel Hill, Chapel Hill, NC 27514, USA \\ * Correspondence: mghall@unc.edu
}

check for updates

Citation: Duffy, E.W.; Taillie, L.S.; Richter, A.P.C.; Higgins, I.C.A.; Harris, J.L.; Hall, M.G. Parental Perceptions and Exposure to Advertising of Toddler Milk: A Pilot Study with Latino Parents. Int. J. Environ. Res. Public Health 2021, 18, 528. https://doi.org/10.3390/ ijerph18020528

Received: 9 December 2020 Accepted: 5 January 2021

Published: 10 January 2021

Publisher's Note: MDPI stays neutral with regard to jurisdictional clai$\mathrm{ms}$ in published maps and institutional affiliations.

Copyright: (C) 2021 by the authors. Licensee MDPI, Basel, Switzerland. This article is an open access article distributed under the terms and conditions of the Creative Commons Attribution (CC BY) license (https:// creativecommons.org/licenses/by/ $4.0 /)$.

\begin{abstract}
Marketing of toddler milk (i.e., typically sugar-sweetened nutrient-fortified milk-based drinks marketed for children 12-36 months) is an emerging public health problem in the US. The American Academy of Pediatrics recommends against the consumption of toddler milk because it often contains added sugar and can displace nutrient-dense foods. Studies have not examined toddler milk perceptions among Latinos, an important gap given Latino children in the US are at high risk of having poor diet quality, and toddler milk is extensively advertised on Spanish-language TV. This study used an online survey of a convenience sample of 58 Latino parents to examine parents' experiences with toddler milk, understand their perceptions of the healthfulness and the nutritionrelated claims on toddler milk, and describe their exposure to toddler milk advertising. Nearly half $(44 \%)$ of parents in the sample reported purchasing toddler milk. When asked to provide open-ended interpretations of claims on toddler milk, almost all parents gave positive answers, suggesting potential "health halo" effects of the claims. More than half (56\%) of parents reported seeing toddler milk advertisements, most commonly on Spanish-language TV. The misperceptions about toddler milk identified should be explored in further research using larger, more representative samples.
\end{abstract}

Keywords: Hispanic Americans; food labeling; child nutrition sciences; pediatric obesity; sugarysweetened beverage

\section{Introduction}

Diet quality in early childhood is a key determinant of longer-term risk of dietrelated chronic diseases [1-3]. A key component of diet quality in early childhood is beverage consumption, as beverages contribute a significant proportion of daily energy and key nutrients such as calcium and vitamin D [4]. The only beverages recommended for consumption in early childhood are water, milk, and a limited amount of $100 \%$ juice if fruit recommendations cannot be met with whole fruit [5]. As a result of a variety of socioecological determinants such as targeted marketing and acculturative stress [6,7], Latino children often have worse diet quality, including higher consumption of sugary drinks and $100 \%$ juice, than non-Latino white children [6-10]. Poor diet quality in early childhood is associated with obesity risk later in childhood, and Latino children in the US are at disproportionate risk of having obesity [11,12]. Public health efforts are urgently needed to improve diet quality and prevent obesity among Latino children in the US. 
One troubling trend in early childhood diet quality and beverage consumption in the US is the promotion of toddler milks [13]. Toddler milks are nutrient-fortified milk-based drinks that are typically sugar-sweetened and marketed for children 12-36 months [5,14]. The American Academy of Pediatrics and other major nutrition and health organizations recommend against consumption of toddler milk because it can interfere with sustained breastfeeding, often contains added sugar, offers no unique nutritional value beyond what an adequate diet can provide [5]. Recommendations state that children younger than two years should not consume added sugars because excessive added sugar intake is associated with diet-related diseases (e.g., obesity, type two diabetes, dental caries) and because added sugar intake in early childhood can contribute to sweet preference development $[5,15]$. Itis also recommended that young children consume a variety of nutrient-dense foods, and toddler milk has the potential to displace these foods. Additionally, the World Health Organization includes toddler milk in its International Code of Marketing of Breastmilk Substitutes (The Code) [16]. The Code, which has not been adopted in the US, calls for the prohibition of marketing these products to the general public, among other provisions [17].

Despite these recommendations, formula companies in the US are focusing on advertising expenditures on toddler milks. Between 2011 and 2015, advertising expenditures on toddler milk in the US increased by $78 \%$, surpassing spending on infant formula advertising expenditures by $\$ 7$ million in 2015 [18]. Analyses of sales data suggest these increases in advertising expenditures are translating into increases in toddler milk sales in the US. Between 2006 and 2015, volume sales of toddler milks in the US increased from 1 million $\mathrm{kg}$ to 3 million $\mathrm{kg}$ [13]. There is also evidence of targeted toddler milk marketing to Latino communities. Toddler milk brands are extensively advertised directly to Latino parents on Spanish-language TV [18]. For example, in 2015, Nido (one popular toddler milk brand) spent all of their TV marketing budget (\$4 million) on Spanish-language TV, and Enfagrow increased their expenditures on Spanish-language TV from \$0 in 2012 to $\$ 5$ million in 2015 [18]. Little research exists on toddler milk consumption in the US, but one study found that Latino parents were more likely than non-Latino White parents to report serving toddler milk to their children [19].

Toddler milks also carry many nutrition or health-related claims on the front of the package [14]. These claims are often what the US Food and Drug Administration (FDA) considers structure/function claims [14]. This category of claims does not require preapproval by the FDA and does not need to be substantiated by scientific evidence [20,21]. Nutrition and health claims increase parents' perceived healthfulness and purchase intentions regardless of a food or beverage's actual nutritional quality [22-25]. Claims often cause what is called a "health halo", where shoppers misinterpret a claim about one product attribute to mean the product is generally healthy [26]. Studies have found that parents generally perceive toddler milks to be healthy despite not being recommended [19,27]. One study examined parents' perceptions of toddler milk claims and found parents believed the claims meant toddler milk provided nutrients other food sources could not provide or that toddler milk was a necessary component of a child's diet [27]. Another study found that parents' agreement with claims on toddler milk packaging was associated with increases in the probability of providing toddler milk to their children [19]. However, no studies have explored perceptions of toddler milk claims among Latino populations.

The objectives of this study were to examine Latino parents' experiences with toddler milk, understand their perceptions of the overall healthfulness of toddler milk and the nutrition-related claims on toddler milk, and describe their exposure to toddler milk advertising using a convenience sample.

\section{Materials and Methods}

\subsection{Participants}

From August to October 2019, we recruited a convenience sample of 61 Latino parents living in North Carolina as part of a pilot study evaluating the impact of sugary drink warnings and taxes on purchases in a naturalistic convenience store laboratory 
(i.e., the "store pilot study."). This sample answered questions about toddler milks as part of their participation in the store pilot study, as described below. The results of the store pilot study will be reported in a separate publication.

We recruited participants for the store pilot study in-person (e.g., at bus stops, laundromats, neighborhoods, local nonprofits) via flyers and by word-of-mouth (e.g., hearing about the study from a friend or family member). To be eligible, participants had to be at least 18 years old, identify as Latino or Hispanic, have at least one child (ages 2-18 years), read and speak English or Spanish, do at least half of the grocery shopping for their household, consume sugary drinks at least once in the last month, purchase at least one non-alcoholic beverage in the previous week, and be able to use a computer or tablet to take surveys. Only one person per household could participate. These eligibility criteria were designed for the purpose of the store pilot study.

\subsection{Procedures}

All study participants provided written informed consent. As part of the main pilot study, participants attended five weekly study visits in a naturalistic convenience store laboratory, where they completed a shopping task (data to be reported separately) and a self-administered online survey, which was programmed using Qualtrics survey software. The toddler milk survey items summarized in this manuscript were included in the self-administered online survey from visit three of the store pilot study. At each visit, participants received an incentive totaling $\$ 45$ ( $\$ 70$ at the fifth visit) in the form of a Visa gift card and grocery items selected during the shopping task. The University of North Carolina Institutional Review Board approved this study. Prior to data collection, this study was pre-registered on AsPredicted.org: http:/ / aspredicted.org/blind.php? $\mathrm{x}=\mathrm{a} 92 \mathrm{mw} 3$.

\subsection{Measures}

Participants chose to take the survey in English or Spanish. A professional translation company translated survey items from English to Spanish. The visit one survey assessed standard demographic measures. This paper reports the results of the visit three survey items regarding toddler milk. Participants viewed images of two toddler milks that are advertised on Spanish-language TV [18] (Nido Kinder 1+ and Enfagrow Toddler Next Step) and a definition of toddler milk that stated these products are different from infant formulas like Enfamil and Similac (for infants younger than 12 months old) to minimize confusion with infant formula.

The survey assessed familiarity with (i.e., ever seeing toddler milk in a store) and reported purchases of toddler milk (never, 1-2 times, 3-4 times, 5-9 times, 10 or more times). Participants were asked why other parents would want their children to drink toddler milk as we were unsure if a substantial proportion of parents would have purchased toddler milk themselves. The survey also assessed exposure to toddler milk advertising and conversations about toddler milk [28].

Participants then viewed an image of Nido Kinder 1+ and responded to questions about familiarity, past purchases, perceived healthfulness (5-point Likert scale from 1 unhealthy to 5 healthy) [29], and perceptions of added sugar content (Nido Kinder 1+ contains added sugar). Two open-ended items assessed interpretations of structure/function claims ("Helps support healthy growth" and "immunity") on the Nido Kinder 1+ package. Exact item wording for all measures available in Supplementary Table S1. Nido Kinder 1+ was selected as the brand for the image and items because of Nido's extensive marketing to Latino communities and because Nido Kinder $1+$ contains added sugar. These items were developed by the study team, which includes individuals with policy and legal expertise related to toddler milks, using some items that were modified from prior studies (i.e., items related to conversations and perceived healthfulness) and some new items designed to address gaps in the existing literature. 


\subsection{Analysis}

Our analytic sample included 58 parents; two parents withdrew from the study before completing the visit three surveys, and one parent did not attend visit three. Descriptive statistics assessed toddler milk familiarity, purchases, other parents' reasons for provision, perceived healthfulness, advertising exposure, and conversations. For the interpretations of claims, we used an inductive coding approach to develop a set of themes after reviewing participants' responses. We then used these themes to develop our codebook that contained the name of each theme, a description of the theme, and examples of quotes that would and would not be coded under each theme. We then coded participants' open-ended responses into themes. Prior to coding, a fluent Spanish speaker $(\mathrm{IH})$ translated all Spanish responses to English. Two coders (ED and AR) double coded all responses, with discrepancies resolved by coder consensus. Due to the small sample size of this pilot study, all data presented are descriptive, and no statistical tests were conducted. Analyses used Stata version 16.1.

\section{Results}

\subsection{Demographic Characteristics}

Participants had a mean age of 35.8 years, and $98 \%$ were female (Table 1). About onequarter $(24 \%)$ had a child younger than three years in their household. About one-third of parents (39\%) had less than a high school degree, and $52 \%$ of parents had a high school degree. Most parents (82\%) had an annual household income of less than $\$ 25,000$. Most participants $(77 \%)$ were overweight or obese. Most participants completed the surveys in Spanish (83\%).

Table 1. Participant demographic characteristics $(n=58)$.

\begin{tabular}{|c|c|c|c|}
\hline & & \multicolumn{2}{|c|}{ Overall } \\
\hline & & $\mathbf{N}$ & $\%$ \\
\hline \multicolumn{4}{|l|}{ Age } \\
\hline & $18-29$ years & 11 & 19 \\
\hline & $30-39$ years & 30 & 52 \\
\hline & $40-49$ years & 16 & 28 \\
\hline & $50+$ years & 1 & 2 \\
\hline & Mean in years $(\mathrm{SD})$ & 35.8 & 6.8 \\
\hline \multicolumn{4}{|c|}{ Gender } \\
\hline & Male & 1 & 2 \\
\hline & Female & 56 & 98 \\
\hline Lating & & 58 & 100 \\
\hline \multicolumn{4}{|c|}{ Years Lived in the US } \\
\hline & Born in the US & 5 & 9 \\
\hline & More than 10 years & 42 & 75 \\
\hline & 10 years or less & 9 & 16 \\
\hline \multicolumn{4}{|c|}{ Educational Attainment } \\
\hline & $\begin{array}{l}\text { Less than a high } \\
\text { school degree }\end{array}$ & 21 & 39 \\
\hline & High school degree & 28 & 52 \\
\hline & $\begin{array}{l}\text { Four-year college } \\
\text { degree }\end{array}$ & 4 & 7 \\
\hline & Graduate degree & 1 & 2 \\
\hline \multicolumn{4}{|c|}{ Household Income } \\
\hline & $\$ 0-\$ 24,999$ & 46 & 82 \\
\hline & $\$ 25,000-\$ 49,999$ & 9 & 16 \\
\hline & $\$ 50,000-\$ 74,999$ & 0 & 0 \\
\hline & $\$ 75,000+$ & 1 & 2 \\
\hline
\end{tabular}


Table 1. Cont.

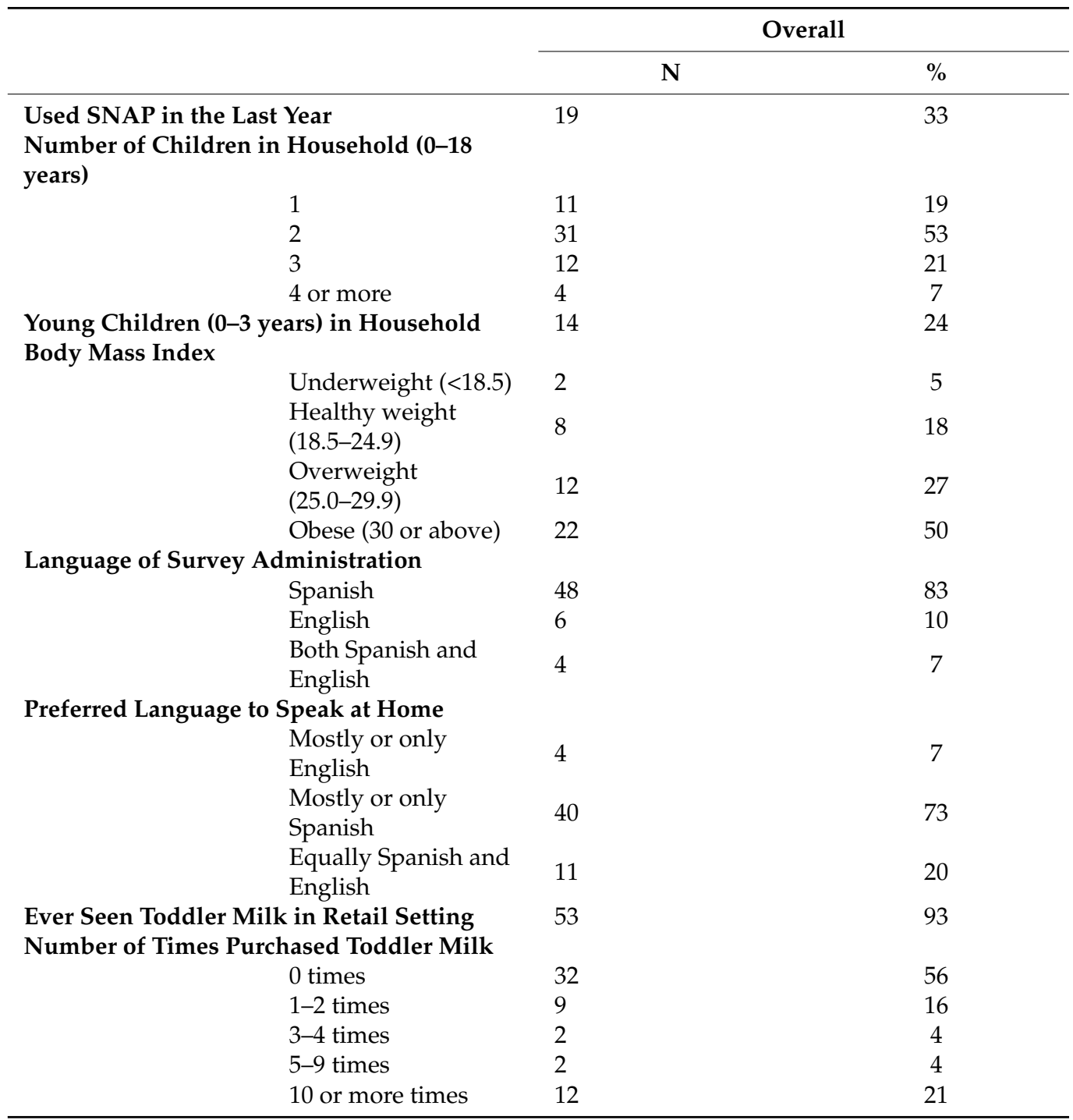

SNAP: Supplemental Nutrition Assistance Program.

\subsection{Familiarity and Purchase Behaviors}

Almost all parents (93\%) were familiar with toddler milk. About half of parents (56\%) reported never purchasing any toddler milk brand, while $23 \%$ had purchased it one to nine times, and $21 \%$ had purchased toddler milk 10 or more times (Table 1 ). When asked about Nido specifically, 98\% (57) of parents were familiar with Nido, and 51\% (29) reported previously purchasing it. When asked why they thought parents would want their children to drink toddler milk, common reasons were to provide nutrients $(72 \%)$, to support growth (52\%), to help with brain development $(41 \%)$, because they grew up drinking toddler milk $(41 \%)$, and because the child likes the taste (28\%) (Figure 1). 


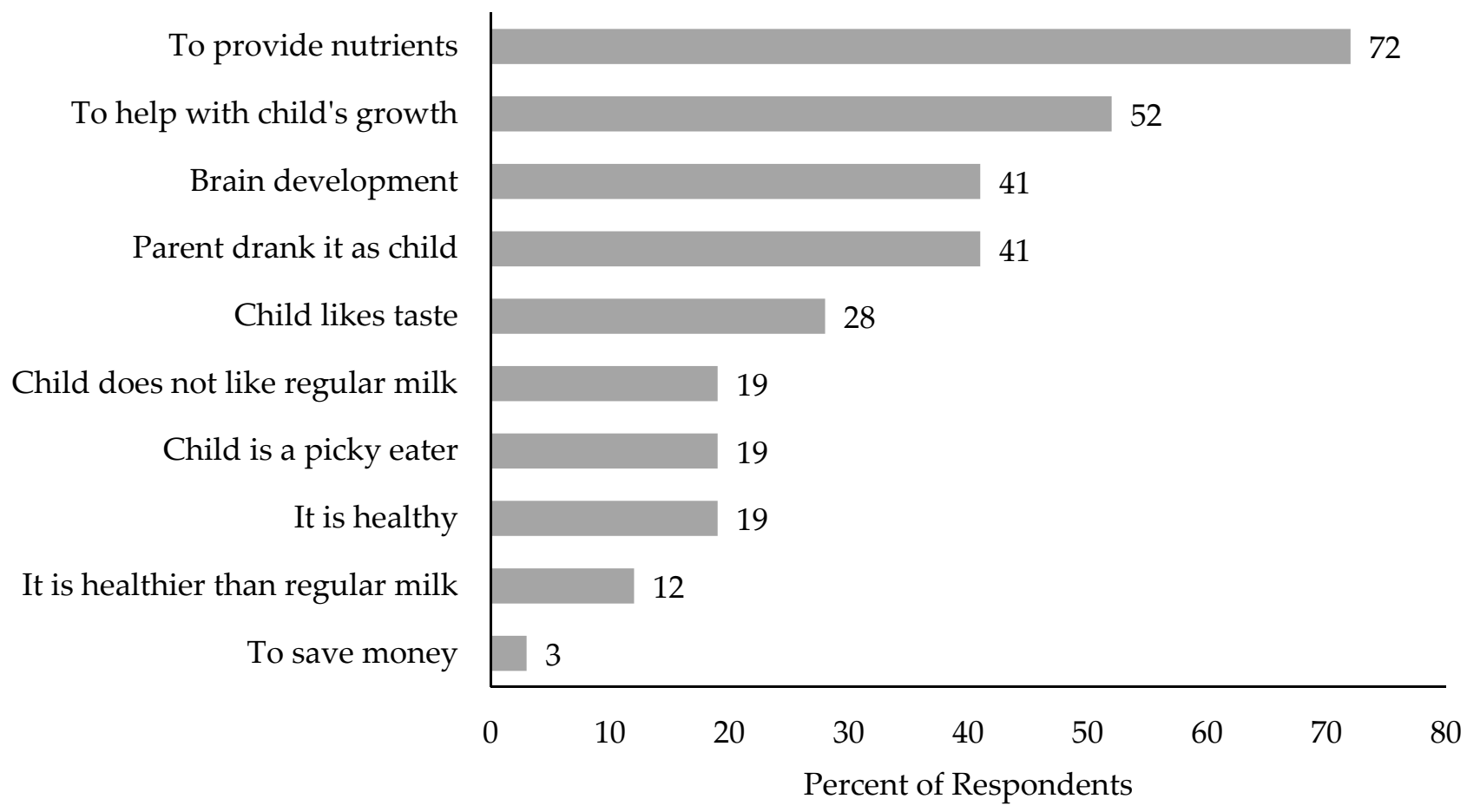

Figure 1. Reasons reported why other parents would want their children to drink toddler milk $(n=58)$.

\subsection{Perceptions of Healthfulness and Product Claims}

About one in four parents $(28 \%, 16)$ incorrectly stated Nido Kinder $1+$ did not contain added sugars. Thirty-nine percent (21) believed it would be healthy for a child to drink toddler milk every day ( $15 \%$ answering 4 and $24 \%$ answering 5 on a 5 -point scale), and only $22 \%$ (12) of parents said it would be unhealthy ( $2 \%$ answering 1 and $20 \%$ answering 2 on a 5-point scale). When asked to provide an open-ended explanation of their healthfulness rating, common responses for healthy ratings included that toddler milk contained vitamins or other beneficial ingredients, it was a healthy product, and that the participant had consumed toddler milk as a child.

When shown an image of Nido Kinder 1+ with the claim "Helps support healthy growth" and asked, "What does the phrase "Helps support healthy growth" tell you about the product?", $40 \%$ of parents mentioned something directly related to growth, such as "It helps the growth of the child" (Table 2). However, many parents interpreted the claim more broadly: 35\% indicated it meant that Nido contained vitamins, minerals, or other nutrients, and 13\% thought it meant Nido supported children's development. When shown an image of Nido Kinder 1+ with the claim "immunity" and asked, "What does the word "immunity" tell you about the product?" most parents $(67 \%)$ thought it meant the product prevented illness or boosted the immune system (Table 3). Seven percent of parents stated the claim meant the product contained vitamins, minerals, or other nutrients ("That their immune systems are reinforced by the vitamins and minerals"). Few (4\%) parents expressed skepticism about either claim (Tables 2 and 3). 
Table 2. Prevalence of themes present in parent interpretations of the "helps support healthy growth" claim on the front of Nido Kinder $1+$ toddler milk packaging.

\begin{tabular}{|c|c|c|c|c|}
\hline \multirow[t]{2}{*}{ Theme } & \multirow[t]{2}{*}{ Description } & \multirow[t]{2}{*}{ Exemplary Quote } & \multicolumn{2}{|c|}{$\begin{array}{c}\text { Prevalence of Theme among } \\
\text { Parent Responses * }\end{array}$} \\
\hline & & & $\mathbf{N}$ & $\%$ \\
\hline Growth & $\begin{array}{l}\text { Reference to the words grow, } \\
\text { growth, or growing or more } \\
\text { general references to getting } \\
\text { bigger, stronger, or taller }\end{array}$ & "It helps children to grow." & 21 & 40 \\
\hline $\begin{array}{l}\text { Vitamins, minerals, and } \\
\text { nutrients }\end{array}$ & $\begin{array}{l}\text { Reference to the product } \\
\text { containing nutrients, vitamins, } \\
\text { or minerals }\end{array}$ & $\begin{array}{l}\text { "It helps children to grow } \\
\text { healthy and it has many } \\
\text { vitamins for children." }\end{array}$ & 18 & 35 \\
\hline General development & $\begin{array}{l}\text { Reference to general or } \\
\text { physical development }\end{array}$ & $\begin{array}{l}\text { "It tells me that it will help my } \\
\text { child to have a healthier } \\
\text { development." }\end{array}$ & 7 & 13 \\
\hline $\begin{array}{l}\text { Immunity and illness } \\
\text { prevention }\end{array}$ & $\begin{array}{c}\text { Reference to the immune } \\
\text { system, immunity, illness, } \\
\text { germs, defense, protection, or } \\
\text { sickness }\end{array}$ & $\begin{array}{c}\text { "It provides vitamins and } \\
\text { nutrients that will prevent } \\
\text { your child from having a weak } \\
\text { immune system or fragile } \\
\text { bones." }\end{array}$ & 4 & 8 \\
\hline Bone or muscle & $\begin{array}{l}\text { Reference to bone or muscle } \\
\text { growth or development }\end{array}$ & $\begin{array}{l}\text { "It helps them to have stronger } \\
\text { bones." }\end{array}$ & 4 & 8 \\
\hline $\begin{array}{l}\text { General health } \\
\text { promotion }\end{array}$ & $\begin{array}{l}\text { Reference to the product being } \\
\text { healthy, promoting health, or } \\
\text { being good for you or for } \\
\text { children }\end{array}$ & "It is healthy for children." & 3 & 6 \\
\hline Meal or milk substitute & $\begin{array}{l}\text { Reference to the product being } \\
\text { a solution to picky eating or } \\
\text { being used as a substitute for } \\
\text { regular milk, breastmilk, or } \\
\text { other foods }\end{array}$ & $\begin{array}{l}\text { "Giving extra support that a } \\
\text { child might not be getting in } \\
\text { their regular meals. Maybe } \\
\text { they don't eat as much fruit or } \\
\text { veggies and this might help } \\
\text { with that part of their diet." }\end{array}$ & 3 & 6 \\
\hline Other ingredients & $\begin{array}{l}\text { Reference to other ingredients } \\
\text { such as macronutrients } \\
\text { (protein, fat, carbohydrates, } \\
\text { sugar), probiotics, hormones, } \\
\text { additives }\end{array}$ & $\begin{array}{l}\text { "That it contains artificial } \\
\text { vitamins to boost children } \\
\text { growth, genetically engineered } \\
\text { hormones in the milk." }\end{array}$ & 2 & 4 \\
\hline Skeptical or misleading & $\begin{array}{l}\text { Reference to the claim being } \\
\text { misleading or untrue or } \\
\text { expression of skepticism about } \\
\text { the claim }\end{array}$ & $\begin{array}{l}\text { "The truth is, I don't think it is } \\
\text { healthy to consume it." }\end{array}$ & 2 & 4 \\
\hline Brain or cognition & $\begin{array}{l}\text { Reference to brain growth or } \\
\text { development or cognitive or } \\
\text { mental development }\end{array}$ & $\begin{array}{l}\text { "It contributes to children's } \\
\text { bone growth and brain } \\
\text { development." }\end{array}$ & 2 & 4 \\
\hline $\begin{array}{l}\text { Positive perception } \\
\text { (not-health related) }\end{array}$ & $\begin{array}{l}\text { Reference to the product } \\
\text { quality, generally liking the } \\
\text { product or other positive } \\
\text { perceptions }\end{array}$ & $\begin{array}{l}\text { "It is good milk for children } \\
\text { that are growing." }\end{array}$ & 1 & 2 \\
\hline
\end{tabular}

* Data missing from 6 participants. Item wording used in survey: “This product says, 'Helps support healthy growth.' What does the phrase "Helps support healthy growth" tell you about the product?" 
Table 3. Prevalence of themes present in parent interpretations of "immunity" claim on the front of Nido Kinder 1+ toddler milk packaging.

\begin{tabular}{|c|c|c|c|c|}
\hline \multirow[t]{2}{*}{ Theme } & \multirow[t]{2}{*}{ Description } & \multirow[t]{2}{*}{ Example Quote } & \multicolumn{2}{|c|}{$\begin{array}{c}\text { Prevalence of Theme among } \\
\text { Parent Responses * }\end{array}$} \\
\hline & & & $\mathbf{N}$ & $\%$ \\
\hline $\begin{array}{l}\text { Immunity and illness } \\
\text { prevention }\end{array}$ & $\begin{array}{l}\text { Reference to the immune } \\
\text { system, immunity, illness, } \\
\text { germs, defense, protection, or } \\
\text { sickness }\end{array}$ & $\begin{array}{l}\text { "Helps them from not getting } \\
\text { sick as often or getting } \\
\text { stronger in fighting off any } \\
\text { type of infection." }\end{array}$ & 31 & 67 \\
\hline $\begin{array}{l}\text { Vitamins, minerals, and } \\
\text { nutrients }\end{array}$ & $\begin{array}{l}\text { Reference to the product } \\
\text { containing nutrients, vitamins, } \\
\text { or minerals }\end{array}$ & $\begin{array}{c}\text { "It helps boost their immune } \\
\text { system by providing key } \\
\text { vitamins." }\end{array}$ & 3 & 7 \\
\hline Skeptical or misleading & $\begin{array}{l}\text { Reference to the claim being } \\
\text { misleading or untrue or } \\
\text { expression of skepticism about } \\
\text { the claim }\end{array}$ & "I'm not sure that this is true." & 2 & 4 \\
\hline Growth & $\begin{array}{l}\text { Reference to the words grow, } \\
\text { growth, or growing or more } \\
\text { general references to getting } \\
\text { bigger, stronger, or taller }\end{array}$ & $\begin{array}{l}\text { "It helps to prevent sickness. It } \\
\text { makes children stronger." }\end{array}$ & 2 & 4 \\
\hline $\begin{array}{l}\text { General health } \\
\text { promotion }\end{array}$ & $\begin{array}{l}\text { Reference to the product being } \\
\text { healthy, promoting health, or } \\
\text { being good for you or for } \\
\text { children }\end{array}$ & "It strengthens your stomach." & 1 & 2 \\
\hline General development & $\begin{array}{l}\text { Reference to general or } \\
\text { physical development }\end{array}$ & $\begin{array}{l}\text { "It can help them to develop } \\
\text { more quickly and get sick less I } \\
\text { think." }\end{array}$ & 1 & 2 \\
\hline $\begin{array}{l}\text { Positive perception } \\
\text { (not-health related) }\end{array}$ & $\begin{array}{l}\text { Reference to the product } \\
\text { quality, generally liking the } \\
\text { product or other positive } \\
\text { perceptions }\end{array}$ & $\begin{array}{l}\text { "Well I think it is good, I don't } \\
\text { know." }\end{array}$ & 1 & 2 \\
\hline
\end{tabular}

* Data missing from 12 participants. Item wording used in survey: “This product says 'immunity'. What does the word'immunity' tell you about the product?"

The prevalence of the themes: bone or muscle, meal or milk substitute, other ingredients, and brain or cognition in parents' interpretations of the "immunity" claim was $0 \%$, so they are not presented in this table.

\subsection{Advertising Exposure and Conversations}

About half of parents $(53 \%, 31)$ reported having seen toddler milk advertisements, including on Spanish-language TV $(68 \%, 21)$, supermarkets $(55 \%, 17)$, social media $(35 \%, 11)$, coupons $(26 \%, 8)$, and retailer websites such as Amazon or Wal-Mart $(26 \%, 8)$. Less common advertising outlets included magazines $(19 \%, 6)$, English-language TV $(16 \%, 5)$, convenience stores or gas stations $(16 \%, 5)$, and parenting websites $(13 \%, 4)$. Parents reported seeing advertisements for Nestle/Nido most often.

Among parents who had purchased toddler milk $(44 \%, 25)$, most $(88 \%, 22)$ reported having at least one conversation related to toddler milk, including with a family member other than their spouse ( $55 \%$ of those who had a conversation, 12$)$, health care providers $(50 \%, 11)$, spouses $(32 \%, 7)$, friends $(27 \%, 6)$, and children $(23 \%, 5)$.

\section{Discussion}

In our study, nearly all Latino parents were familiar with toddler milk and few perceived it to be an unhealthy product, consistent with prior studies [19,27]. Furthermore, more than one-quarter incorrectly believed toddler milk does not contain added sugars. A common reason 
mentioned for why parents believed toddler milk was healthy was because they grew up drinking it, suggesting that cultural norms may play a role in the provision of toddler milk in Latino communities. Future studies could examine this finding further using qualitative methods and examine differences by acculturation status and Hispanic country of origin as The Code is only enforced in five Latin American countries [30]. Additionally, many parents $(44 \%)$ in our study reported purchasing toddler milk at least once in the past, but $56 \%$ reported they had never purchased toddler milk. These findings should be explored further using larger samples, and food purchasing data and parent demographic characteristics associated with regular toddler milk purchases should be examined.

Few parents expressed skepticism about toddler milk packaging claims, also consistent with studies finding that parents generally agree with toddler milk marketing claims [19,27]. Parents had broad interpretations of a claim about healthy growth, stating that they thought the claim meant that toddler milk contained vitamins and helped with brain development. This finding suggests this claim may create a "health halo" effect (i.e., in which consumers interpret a claim about one product attribute to mean the product is generally healthy) as these attributes were not explicitly mentioned in the claim [26]. Parents also generally had favorable interpretations of a claim about immunity, with many stating the claim meant toddler milk would prevent illness or that it contained vitamins to prevent illness. These responses are in line with evidence that immunity claims mislead consumers, which has led to action by the Federal Trade Commission (FTC) against food companies for using claims about immunity [31]. In addition to further FTC action to prevent misleading marketing, experts have called for FDA to issue industry guidance to limit the use of structure/function claims on toddler milk, similar to what they have proposed for claims on infant formula. Additionally, Congressional action could require the FDA to create a new regulatory framework specifically for claims on products marketed to children 36 months and younger [32]. This framework could require that foods and beverages meet specific nutrition standards to carry claims [32].

About half of the parents in our study reported exposure to toddler milk advertisements, most commonly on Spanish-language TV, and the most common advertised brand was Nestle/Nido. Aggressive toddler milk advertising in the US has contributed to sales increases nationwide [13], and in 2015 Nido spent $\$ 4$ million on TV advertising, exclusively on Spanish-language TV [18]. Additionally, Enfagrow did not advertise toddler milk on Spanish-language TV prior to 2012 but increased their advertising expenditures to more than $\$ 5$ million on Spanish-language TV by 2015 [18]. In addition to TV advertising, many parents reported seeing advertisements for toddler milk in supermarkets and on social media. Formula companies purchase consumer data such as whether or not mothers have created a baby registry, posted on Facebook about a pregnancy, or purchased baby items to target parents with advertisements on social media platforms [33], so it is plausible these tactics are also employed for toddler milk advertising. Future research could explore the extent to which Latino parents may be targeted by toddler milk advertisements in other avenues such as in-store marketing (e.g., end cap displays) in Latino grocery stores or on social media platforms.

A strength of this study is its primarily Spanish-speaking Latino sample. Although this was a small convenience sample of parents that are not representative of the larger US Latino population, and some of whom did not currently have a child less than three in the household, both of which limit the external validity of this study. Additionally, some parents viewed a sugary drink warning or tax in the pilot study, which could have reduced their toddler milk healthfulness perceptions. The use of some survey items that have not been validated or tested for reliability is also a limitation. We asked parents why they believed other parents would want their children to drink toddler milk, not knowing how common toddler milk provision would be among our sample. However, future studies should explore parents' own reasons for providing toddler milk. In addition, participants needed to be comfortable using a computer to participate in the study, potentially excluding some parents with limited computer literacy. Some parents may have confused toddler milk 
with infant formula, potentially leading to measurement error. However, multiple steps were taken to reduce confusion with infant formula, such as providing a clear definition of toddler milk at the start of the survey as well as the use of images of Nido, a brand that does not produce infant formula, as the example of toddler milk throughout the survey. Finally, the results presented on parents' interpretations of claims cannot be generalized to all brands of toddler milks.

\section{Conclusions}

The misperceptions about toddler milk identified in this study should be addressed through future research that may inform policy changes such as action by Congress, the FTC, or FDA to prevent misleading labeling of toddler milk and targeted marketing of toddler milk to Latino communities [14,32]. Additionally, some parents reported discussing toddler milk with health care providers. This finding should be explored further, as other studies have documented formula companies' use of health workers and healthcare settings to promote their products [17]. Finally, given the high percentage of our sample that reported previously purchasing toddler milk, it will be important to use nationally representative studies such as the National Health and Nutrition Examination Survey to understand if many Latino children are consuming toddler milk regularly and if there are disparities in toddler milk consumption in the US.

Supplementary Materials: The following are available online at https:/ / www.mdpi.com/1660-460 1/18/2/528/s1, Table S1: Toddler milk survey items.

Author Contributions: Conceptualization, M.G.H., E.W.D. and L.S.T.; methodology, M.G.H., E.W.D. and L.S.T.; formal analysis, E.W.D. with contributions from I.C.A.H., A.P.C.R. and M.G.H.; writingoriginal draft preparation, E.W.D.; writing - review and editing, L.S.T., A.P.C.R., I.C.A.H., J.L.H. and M.G.H.; funding acquisition, L.S.T. and M.G.H. All authors have read and agreed to the published version of the manuscript.

Funding: This project was supported by the National Center for Advancing Translational Sciences (NCATS), National Institutes of Health, through Grant Award Number UL1TR002489. MGH was supported by K01HL147713 from the National Heart, Lung, and Blood Institute of the National Institutes of Health. The content is solely the responsibility of the authors and does not necessarily represent the official views of the NIH. EWD, MGH, APCR, and LST receive general support from the Carolina Population Center (P2C HD050924).

Institutional Review Board Statement: The study was conducted according to the guidelines of the Declaration of Helsinki, and approved by the Institutional Review Board of the University of North Carolina at Chapel hill (protocol code 19-0277, approved 23 May 2019).

Informed Consent Statement: Informed consent was obtained from all subjects involved in the study.

Data Availability Statement: The datasets generated and/or analyzed during the current study are not publicly available due to IRB restrictions, but are available from the corresponding author on reasonable request.

Conflicts of Interest: The authors declare no conflict of interest.

\section{References}

1. Skinner, J.D.; Carruth, B.R.; Wendy, B.; Ziegler, P.J. Children's food preferences: A longitudinal analysis. J. Am. Diet. Assoc. 2002, 102, 1638-1647. [CrossRef]

2. Okubo, H.; Crozier, S.R.; Harvey, N.C.; Godfrey, K.M.; Inskip, H.M.; Cooper, C.; Robinson, S.M. Diet quality across early childhood and adiposity at 6 years: The Southampton Women's Survey. Int. J. Obes. 2015, 39, 1456-1462. [CrossRef] [PubMed]

3. Dixon, H.; Scully, M.; Niven, P.; Kelly, B.; Chapman, K.; Donovan, R.; Martin, J.; Baur, L.A.; Crawford, D.; Wakefield, M. Effects of nutrient content claims, sports celebrity endorsements and premium offers on pre-adolescent children's food preferences: Experimental research. Pediatr. Obes. 2014, 9, e47-e57. [CrossRef] [PubMed]

4. Kay, M.C.; Welker, E.B.; Jacquier, E.F.; Story, M.T. Beverage Consumption Patterns among Infants and Young Children (0(-)47.9 Months): Data from the Feeding Infants and Toddlers Study, 2016. Nutrients 2018, 10, 825. [CrossRef] [PubMed] 
5. Lott, M.; Callahan, E.; Welker Duffy, E.; Story, M.; Daniels, S. Healthy Beverage Consumption in Early Childhood: Recommendations from key National Health and Nutrition Organizations; Technical Scientific Report; Healthy Eating Research: Durham, NC, USA, 2019; Available online: http:/ / healthyeatingresearch.org (accessed on 5 May 2020).

6. Harris, J.L.; Frazier, W.; Kumanyika, S.; Ramirez, A.G. Increasing Disparities in Unhealthy Food Advertising Targeted to Hispanic and Black Youth; UConn Rudd Center for Food Policy \& Obesity: Storrs, CT, USA, 2019.

7. Figueroa, R.; Isasi, C.R.; Perreira, K.M.; McClain, A.C.; Gallo, L.C.; Sotres-Alvarez, D.; Delamater, A.M.; Daviglus, M.; Van Horn, L.; Mattei, J. Targeting family functioning, acculturative stress, and sugar-sweetened beverage consumption for obesity prevention: Findings from the Hispanic community children's health study/study of Latino youth. BMC Public Health 2020, 20, 1546. [CrossRef] [PubMed]

8. Ahluwalia, N. Nutrition Monitoring of Children Aged Birth to 24 Mo (B-24): Data Collection and Findings from the NHANES. Adv. Nutr. 2020, 11, 113-127. [CrossRef]

9. Grimes, C.A.; Szymlek-Gay, E.A.; Nicklas, T.A. Beverage consumption among US children aged 0-24 months: National Health and Nutrition Examination Survey (NHANES). Nutrients 2017, 9, 264. [CrossRef]

10. Miles, G.; Siega-Riz, A.M. Trends in food and beverage consumption among infants and toddlers: 2005-2012. Pediatrics 2017, 139, e20163290. [CrossRef]

11. Hales, C.M.; Fryar, C.D.; Ogden, C.L. Prevalence of Obesity Among Adults and Youth: United States, 2015-2016. NCHS Data Brief. 2017. Available online: https://www.cdc.gov/nchs/data/databriefs/db288.pdf (accessed on 25 November 2020).

12. Ogden, C.L.; Carroll, M.D.; Flegal, K.M. High Body Mass Index for Age Among US Children and Adolescents, 2003-2006. JAMA 2008, 299, 2401-2405. [CrossRef]

13. Choi, Y.Y.; Ludwig, A.; Harris, J.L. US toddler milk sales and associations with marketing practices. Public Health Nutr. 2020, 23, 1127-1135. [CrossRef] [PubMed]

14. Pomeranz, J.L.; Palafox, M.J.R.; Harris, J.L. Toddler drinks, formulas, and milks: Labeling practices and policy implications. Prev. Med. 2018, 109, 11-16. [CrossRef]

15. Vos, M.B.; Kaar, J.L.; Welsh, J.A.; Van Horn, L.V.; Feig, D.I.; Anderson, C.A.M.; Patel, M.J.; Cruz Munos, J.; Krebs, N.F.; Xanthakos, S.A.; et al. Added Sugars and Cardiovascular Disease Risk in Children: A Scientific Statement From the American Heart Association. Circulation 2017, 135, e1017-e1034. [CrossRef] [PubMed]

16. World Health Organization. World Health Assembly Resolution on the Inappropriate Promotion of Foods for Infants and Young Children. 2016. Available online: https://www.who.int/nutrition/netcode/WHA-Policy-brief.pdf (accessed on 20 December 2020).

17. Harris, J.L.; Pomeranz, J.L. Infant formula and toddler milk marketing: Opportunities to address harmful practices and improve young children's diets. Nutr. Rev. 2020, 78, 866-883. [CrossRef] [PubMed]

18. Harris, J.L.; Fleming-Milici, F.; Frazier, W.; Haraghey, K.; Rodriguez-Arauz, G.; Heller, R.; Hubbard, W. Baby Food Facts: Nutrtition and Marketing of Baby and Toddler Food and Drinks; UConn Rudd Center for Food Policy \& Obesity: Storrs, CT, USA, 2017.

19. Romo-Palafox, M.J.; Pomeranz, J.L.; Harris, J.L. Infant formula and toddler milk marketing and caregiver's provision to young children. Matern. Child Nutr. 2020, e12962. [CrossRef] [PubMed]

20. U.S. Food and Drug Administration Center for Food Safety and Applied Nutrition. A Food Labeling Guide: Guidance for Industry; Food and Drug Administration: College Park, MD, USA, 2013.

21. Code of Federal Regulations Title 21 §101.93. Certain Types of Statements for Dietary Supplements. 2019. Available online: https: / / www.law.cornell.edu/cfr/text/21/101.93 (accessed on 12 June 2020).

22. Bech-Larsen, T.; Grunert, K.G. The perceived healthiness of functional foods. A conjoint study of Danish, Finnish and American consumers' perception of functional foods. Appetite 2003, 40, 9-14. [CrossRef]

23. André, Q.; Chandon, P.; Haws, K. Healthy Through Presence or Absence, Nature or Science?: A Framework for Understanding Front-of-Package Food Claims. J. Public Policy Mark. 2019, 38, 172-191. [CrossRef]

24. Aschemann-Witzel, J.; Hamm, U. Do consumers prefer foods with nutrition and health claims? Results of a purchase simulation. J. Mark. Commun. 2010, 16, 47-58. [CrossRef]

25. Hall, M.G.; Lazard, A.J.; Grummon, A.H.; Mendel, J.R.; Taillie, L.S. The impact of front-of-package claims, fruit images, and health warnings on consumers' perceptions of sugar-sweetened fruit drinks: Three randomized experiments. Prev. Med. 2020, 132. [CrossRef]

26. Burton, S.; Cook, L.A.; Howlett, E.; Newman, C.L. Broken halos and shattered horns: Overcoming the biasing effects of prior expectations through objective information disclosure. J. Acad. Mark. Sci. 2015, 43, 240-256. [CrossRef]

27. Romo-Palafox, M.J. Marketing Claims on Infant Formula and Toddler Milk Packages: What do Caregivers think they Mean? UConn Rudd Center for Food Policy \& Obesity: Storrs, CT, USA, 2019.

28. Hall, M.G.; Peebles, K.; Bach, L.E.; Noar, S.M.; Ribisl, K.M.; Brewer, N.T. Social interactions sparked by pictorial warnings on cigarette packs. Int. J. Environ. Res. Public Health 2015, 12, 13195-13208. [CrossRef] [PubMed]

29. Bollard, T.; Maubach, N.; Walker, N.; Mhurchu, C.N. Effects of plain packaging, warning labels, and taxes on young people's predicted sugar-sweetened beverage preferences: An experimental study. Int. J. Behav. Nutr. Phys. Act. 2016, 13, 95. [CrossRef] [PubMed]

30. Lutter, C.K. The International Code of Marketing of Breast-milk Substitutes: Lessons learned and implications for the regulation of marketing of foods and beverages to children. Public Health Nutr. 2013, 16, 1879-1884. [CrossRef] [PubMed] 
31. Federal Trade Commission. FTC Investigation of Ad Claims that Rice Krispies Benefits Children's Immunity Leads to Stronger Order Against Kellogg. June 2010. Available online: https:/ / www.ftc.gov/news-events/press-releases/2010/06/ftc-investigationad-claims-rice-krispies-benefits-childrens (accessed on 12 September 2020).

32. Pomeranz, J.L.; Harris, J.L. Federal Regulation of Infant and Toddler Food and Drink Marketing and Labeling. Am. J. Law Med. 2019, 45, 32-56. [CrossRef] [PubMed]

33. Wilking, C. Reducing Digital Marketing of Infant Formulas. The Public Health Advocacy Instituute. 2020. Available online: https: / / www.phaionline.org/wp-content/uploads/2020/11/IF-Digital-Marketing-Full-Report-Nov-2020.pdf (accessed on 5 December 2020). 